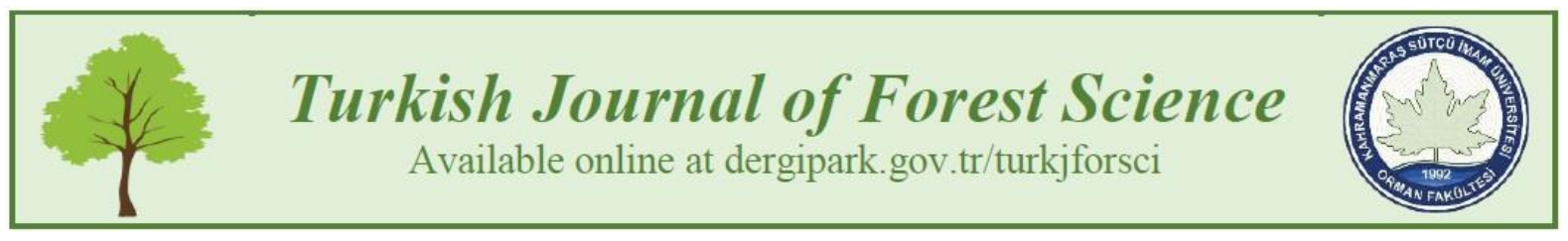

\title{
DESIGNING A WEB APPLICATION FOR NECIP FAZIL KISAKUREK PARK, KAHRAMANMARAS, TURKEY
}

\author{
Milat Hasan Abdullah ABDULLAH ${ }^{1}$, Hakan OGUZ ${ }^{2}$, Fatih TONGUC ${ }^{3, *}$ \\ ${ }^{1}$ Department of Social Science, College of Basic Education, University of Zakho, Duhok, Iraq \\ ${ }^{2}$ Department of Landscape Architecture, Faculty of Forestry, Kahramanmaras Sutcu Imam University, \\ Kahramanmaras, Turkey \\ ${ }^{3}$ Department of Forest Engineering, Faculty of Forestry, Isparta Applied Sciences University, Isparta, Turkey \\ "Corresponding author: fatihtonguc@isparta.edu.tr
}

Milat Hasan Abdullah ABDULLAH: https://orcid.org/0000-0002-0919-3676

Hakan OGUZ: https://orcid.org/0000-0002-0855-2032

Fatih TONGUC: https://orcid.org/0000-0002-0820-4820

Please cite this article as: Abdullah, M. H. A., Oguz, H. \& Tonguc, F. (2021) Designing a web application for Necip Fazil Kisakurek Park, Kahramanmaras, Turkey. Turkish Journal of Forest Science, 5(2), 620-633

\author{
ESER BILGISI / ARTICLE INFO \\ Araştırma Makalesi / Research Article \\ Geliş 15 Eylul 2021 / Received 15 September 2021 \\ Düzeltmelerin gelişi 4 Ekim 2021 / Received in revised form 4 October 2021 \\ Kabul 30 Ekim 2021 / Accepted 30 October 2021 \\ Yayımlanma 31 Ekim 2021 / Published online 31 October 2021
}

\begin{abstract}
As we all know; trees are the true assets of urban areas and they are also part of our community's infrastructure. Thus, they require care and maintenance same as other public properties in the cities. Trees may cause personal injury or property damage without proper care. The aim of this study was to design a web application for the Necip Fazil Kisakurek Park, located in the district of Onikisubat, Kahramanmaras, Turkey. This study was conducted in two parts. In the first part, an inventory for trees in the park was conducted. GPS coordinates, tree height, diameter at breast height, tree type (Deciduous/Evergreen) of each individual tree were gathered with ground measurements and field observations. Attributes of 70 trees were retrieved during the inventory. After the tree inventory, a total of 19 different species were identified where Fraxinus was found to have the largest number of trees with 18 in the study area. In the second part, a database was designed for the trees inventoried and then two web apps (applications) were created. The first web app was created for general public using ArcGIS Online. Attributes of each tree are given to the user via popup window in this web app. This app is publicly accessible and users may interact with the app via browsers by personal computers, tablets, or smartphones. The second web app is designed for local government utilities only in order to manage tree information in the Necip Fazil Kisakurek Park. With this app, local authorities will be able to edit and update tree information in the park. This app will only be accessible to local authorities and not to general public.
\end{abstract}

Keywords: ArcGIS Online, GIS, Inventory, Urban Trees, Web App. 


\section{NECİP FAZIL KISAKÜREK PARKI İÇIN BİR WEB UYGULAMASI, KAHRAMANMARAŞ, TÜRKIYYE}

ÖZET: Hepimizin bildiği gibi ağaçlar kentsel alanlardaki gerçek varlıkları ve aynı zamanda topluluğumuzun altyapısının bir parçasıdır. Bu nedenle, diğer kamu mülkleriyle aynı bakım ve bakıma ihtiyaç duyarlar. Uygun bakım olmadan, ağaçlar kişisel yaralanmaya veya mülkiyet hasarına neden olabilir. Bu çalışmanın amacı, Kahramanmaraş'ın Onikişubat ilçesinde yer alan Necip Fazıl Kısakürek Parkı için bir web uygulamasının tasarlanmasıdır. $\mathrm{Bu}$ çalışma iki aşamada gerçekleştirilmiştir. Bu çalışmanın ilk bölümünde parkta yer alan ağaçlar için bir envanter çalışması yapılmıştır. Her bir ağaç için koordinat, boy, göğüs yüksekliğindeki çap ve ağaç türü (iğneli/yapraklı) gibi bilgiler saha çalışması yapılarak elde edilmiştir. Envanter çalışmasında toplam 70 ağacın bilgileri elde edilmiştir. Envanter çalışması sonucunda 19 farklı tür tespit edilmiş ve Dişbudak 18 ağaç ile en fazla sayıya sahip tür olarak bulunmuştur. Araştırmanın ikinci bölümünde, envanteri yapılan ağaçların özellikleri bir veri tabanına aktarıldıktan sonra ArcGIS Online ile iki web uygulaması (Web App) oluşturulmuştur. İlk uygulama ile parkta yer alan her bir ağacın özellikleri tüm kullanicılara pop-up pencere ile sunulmaktadır. İnteraktif lejanta sahip olan bu web uygulaması internet bağlantısı olan herkesin erişimine açıktır. Bu web uygulamasına kişisel bilgisayar, tablet veya akıllı telefonlar ile erişilebilmektedir. İkinci uygulama ise sadece yerel yöneticiler için tasarlanmıştır. Sadece yöneticiler parktaki ağaç bilgilerini değiştirebilecek ve güncelleyebilecektir. Bu uygulamanın erişimi herkese açık değildir.

Anahtar kelimeler: ArcGIS Online, CBS, Envanter, Kent Ağaçları, Web Uygulaması.

\section{INTRODUCTION}

Trees have environmental, economic, and social benefits. They improve water, soil, and air quality, lower energy bills with their shade, provide shelter for wildlife, and add beauty, aesthetics and value to our house or land, and increase recreational opportunities (Wolf, 1998; Li \& Qi, 2003; Gül et al., 2005; Sabuncu et al., 2013; Bruno et al., 2014). They are also renewable resources and provide ecologic, cultural, and esthetic benefits to communities and local governments. (Gül vd., 2014). On the other hand, trees may cause personal injury or property damage without proper care. Therefore they require care and maintenance same as other public properties in the cities. Designing a web application helps health and maintenance status of individual trees.

During the tree inventory, the total number of trees, species, individual tree properties, gps coordinates, health and maintenance status of individual tree can be obtained. Thus, all kind of data related to urban trees should be gathered and imported into geographic information system (GIS). By doing tree inventory in the urban parks with the help of GIS, it could be possible to assess the current status of the trees, sustainable and effective planning, design, and management for the future. Unfortunately, there are few studies related to web-based tree inventory and almost all of them were done in the last decade (Abd-Elrahman et al., 2010; Gül et al., 2014; Oguz and Kisakurek, 2016a; Oguz and Kisakurek, 2016b; Oguz et al., 2017; Oguz and Isbir, 2017; Oguz et al., 2018; Oguz and Çayraz, 2019; Oguz et al., 2020). 
The aim of this study was to develop two web apps (applications) for the Necip Fazil Kisakurek Park in Kahramanmaraş Turkey. This study was accomplished in two parts. In the first part, an inventory was conducted for trees in the park. During the inventory, gps coordinates and individual attributes such as tree height, dbh, and type of each tree were gathered via ground measurements and field observations. In the second part, all the data obtained during the inventory were imported into ESRI ArcGIS in order to create a geodatabase. Then, two web apps, one for general public and the other for local government utilities were created.

\section{MATERIALS AND METHODS}

Necip Fazil Kisakurek Park is located in Onikisubat, one of the two central districts of Kahramanmaras. The park covers approximately an area of $2651 \mathrm{~m}^{2}$ and is home to 70 trees with 19 species. The park was established in 2001 by Kahramanmaras Municipality and named after the great poet, novelist, playwright, Necip Fazil Kisakurek. Location map of the park was illustrated in Figure 1 below. 


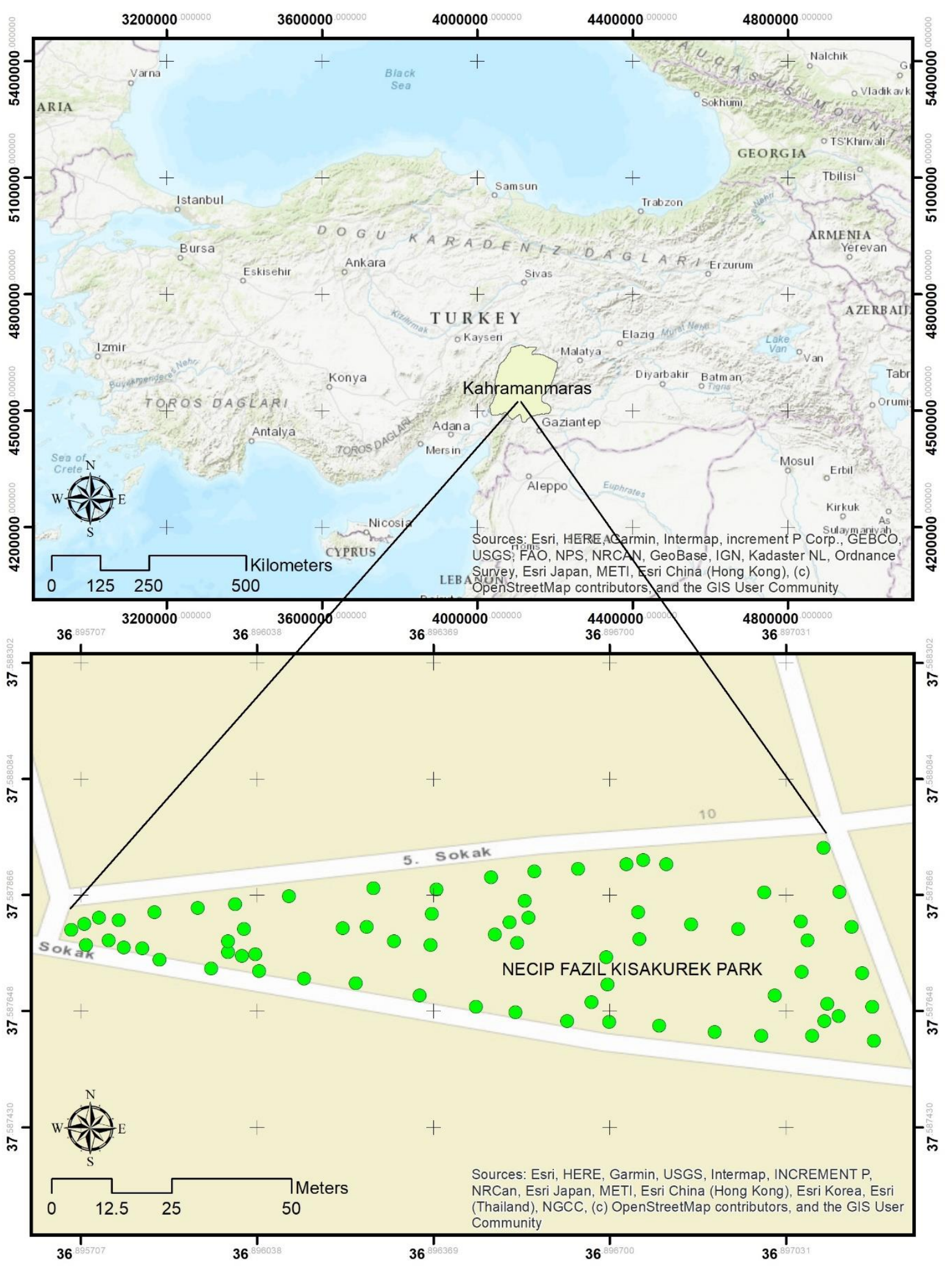

Figure 1. Location map of Necip Fazil Kisakurek Park

This study was completed in two phases. In the first phase, an inventory for trees in the park was conducted. GPS coordinates, tree height $(\mathrm{m}), \mathrm{dbh}(\mathrm{cm})$, and tree type of each individual tree were gathered with field measurements and observations. Attributes of 70 trees were 
retrieved during the inventory. In this first phase, Leica Zeno $20^{\mathrm{TM}}$ was used to record accurate geographic locations of each tree in the study area. Haglof Vertex IV was employed in order to measure the tree heights. A simple tape measure was used to obtain dbh. An ID number was given to each tree in the park and then each tree was photographed. Scientific and Turkish names of each tree were also recorded. In the second phase of this study, a database was created for all the trees inventoried and then two web apps were designed. First web app was created for general public using ArcGIS Online for web-based tree information system. Attributes of each tree in the park are given to the user via pop-up window in this web app. This app is publicly accessible to anyone who has access to internet. Users may interact with the app via browsers in personal computers, tablets, or smartphones. The second web app however is designed specifically for local authorities so that they can edit and update tree information in the park. This second app is not accessible to general public.

\section{RESULTS}

As a result of this study, 19 different species (among 70 trees) were identified in the Necip Fazil Kisakurek Park as shown in Table 1 below.

Table 1. Tree species identified in Necip Fazil Kisakurek Park.

\begin{tabular}{lc}
\hline Species & Number of Trees \\
\hline Fraxinus angustifolia Vahl. L. & 14 \\
Acer negundo L. & 9 \\
Platanus orientalis L. & 8 \\
Thuja orientalis L. & 7 \\
Pyracantha coccinea & 5 \\
Fraxinus ornus L. & 4 \\
Robinia pseudoacacia L. & 3 \\
Ligustrum vulgare & 3 \\
Eleagnus angustifolia L. & 3 \\
Thuja occidentalis & 2 \\
Philadelphus coronarius & 2 \\
Gleditschia triacanthos L. & 2 \\
Washingtonia robusta H. Wendl. & 2 \\
Ulmus carpinifolia & 1 \\
Morus alba L. & 1 \\
Pinus brutia Ten. & 1 \\
Cedrus libani A. Rich. & 1 \\
Pyrus amygdaliformis & 1 \\
Lagerstroemia indica & 1 \\
\hline TOTAL & 70 \\
\hline
\end{tabular}

Fraxinus angustifolia Vahl. L. has the largest distribution with 14 trees in the study area. Acer negundo L. takes the second place with 9 trees. According to tree type, deciduous trees take the lead with 52 while only 18 trees are evergreen in the study area.

After the tree inventory, two web apps were developed for Necip Fazil Kisakurek Park. The first web app was created for general public using ArcGIS Online as illustrated in Figure 2 
below. Attributes of each tree in the park are given to the user via pop-up window in this web app as shown in Figure 3. It is publicly accessible to anyone who has access to internet. Users may interact with the web app via browsers in personal computers, tablets, or smartphones. A full-size photo will be opened in the browser if a user clicks on a thumbnail of a tree in the pop-up window as seen in Figure 4. Users may also query on trees based on attributes using the query tool as seen in Figure 5 below. Queries can be applied to scientific and Turkish names, tree types, dbh and height of trees.

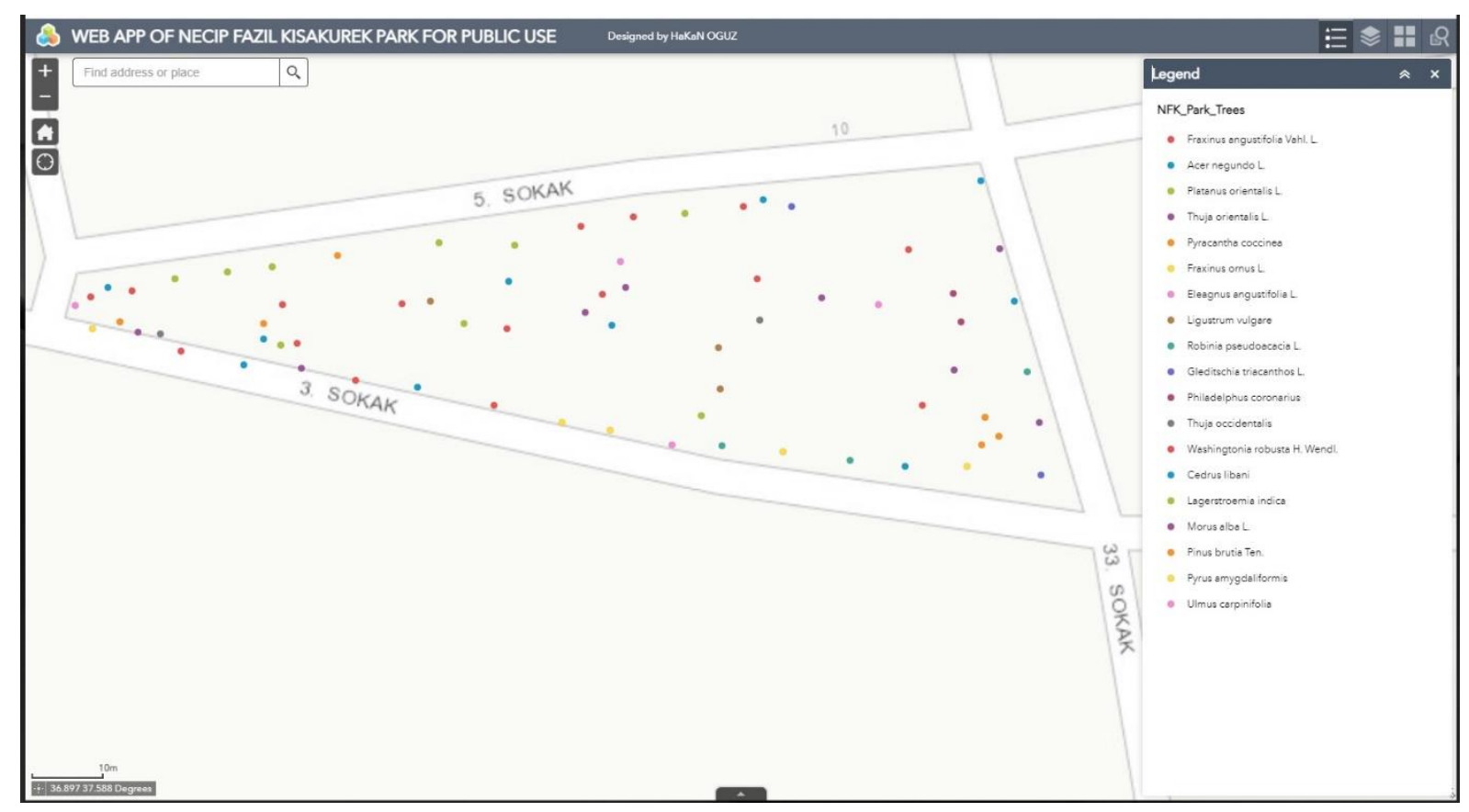

Figure 2. The web app designed for general public

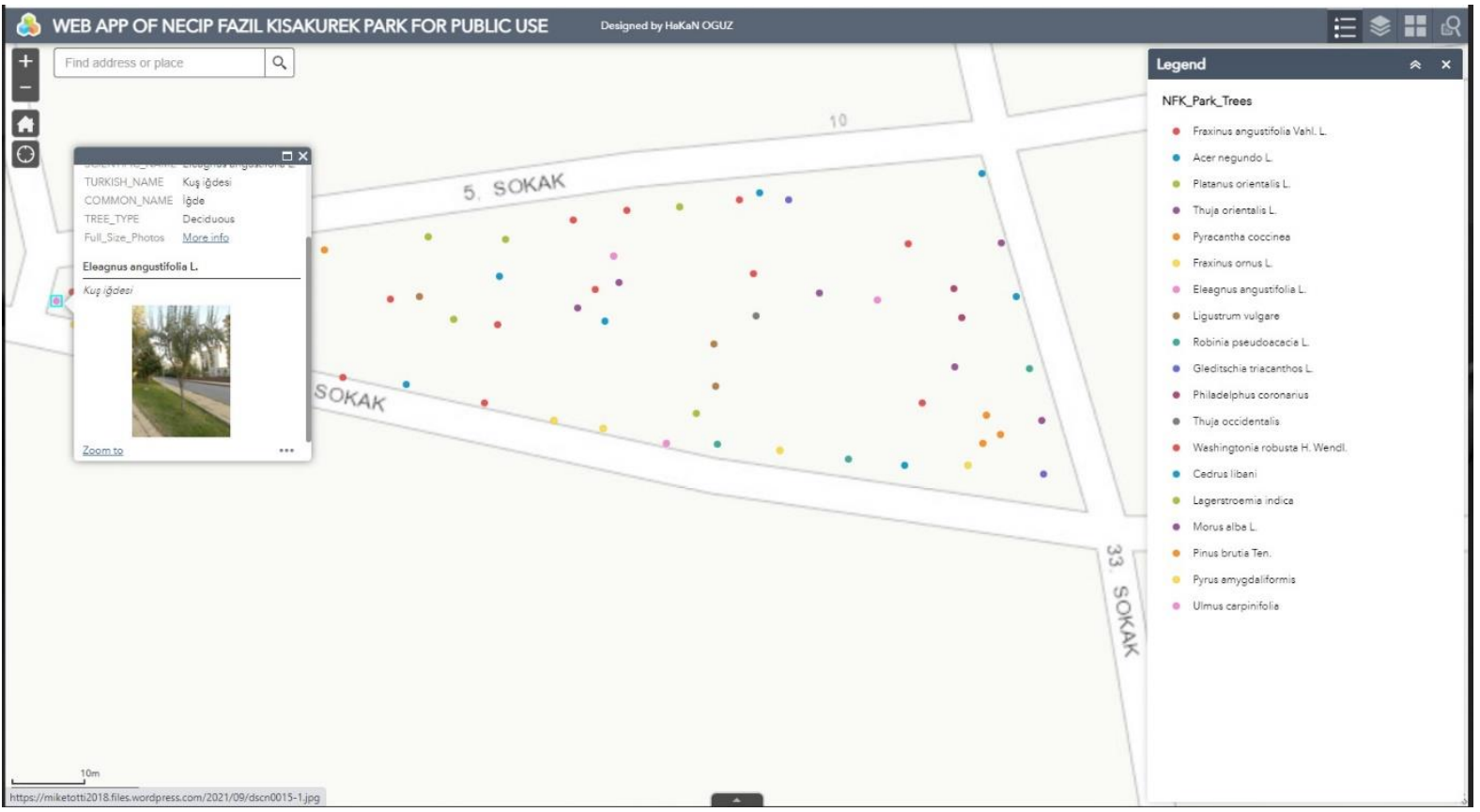

Figure 3. Pup-up window in web app 


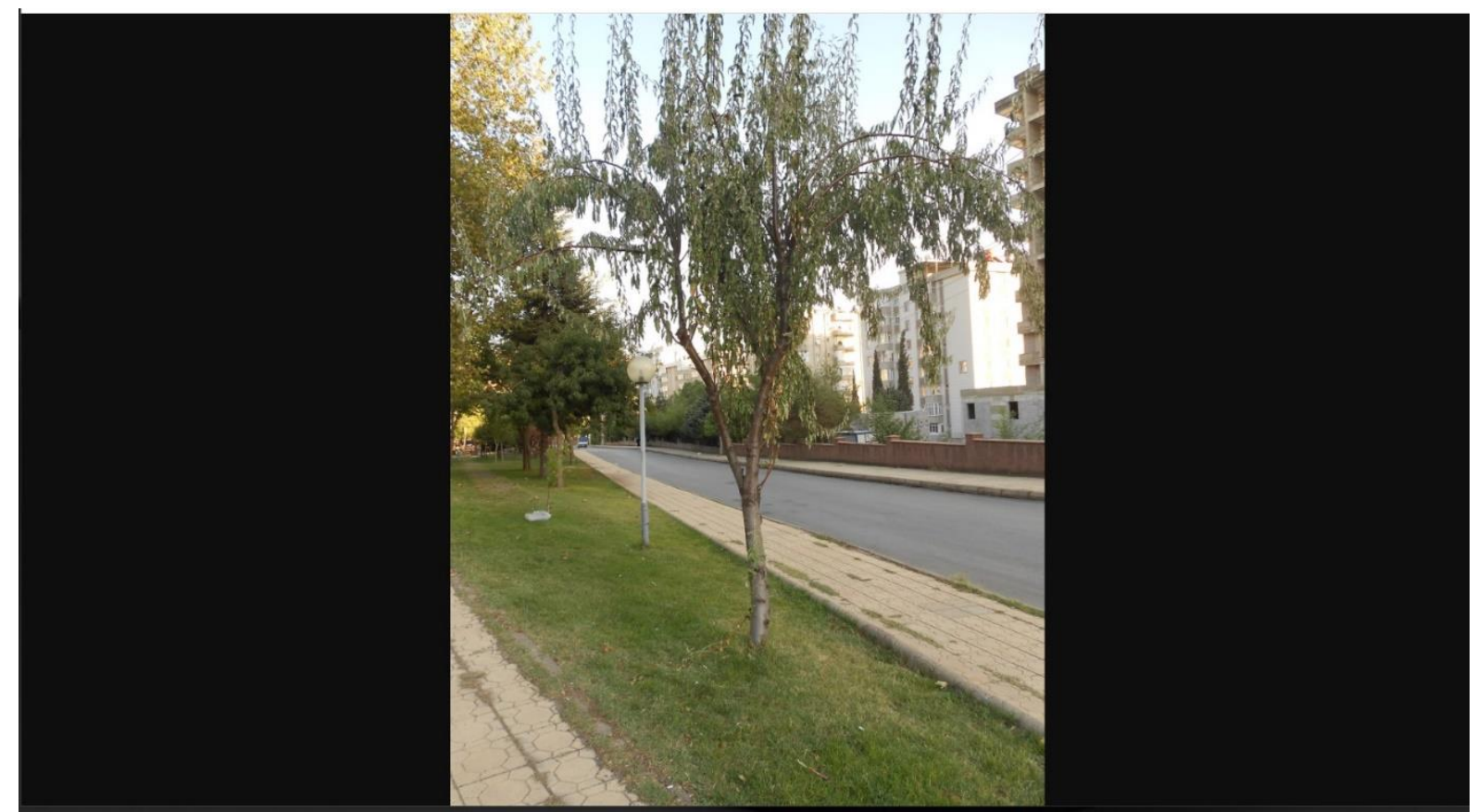

Figure 4. Full size photo of a tree in the park

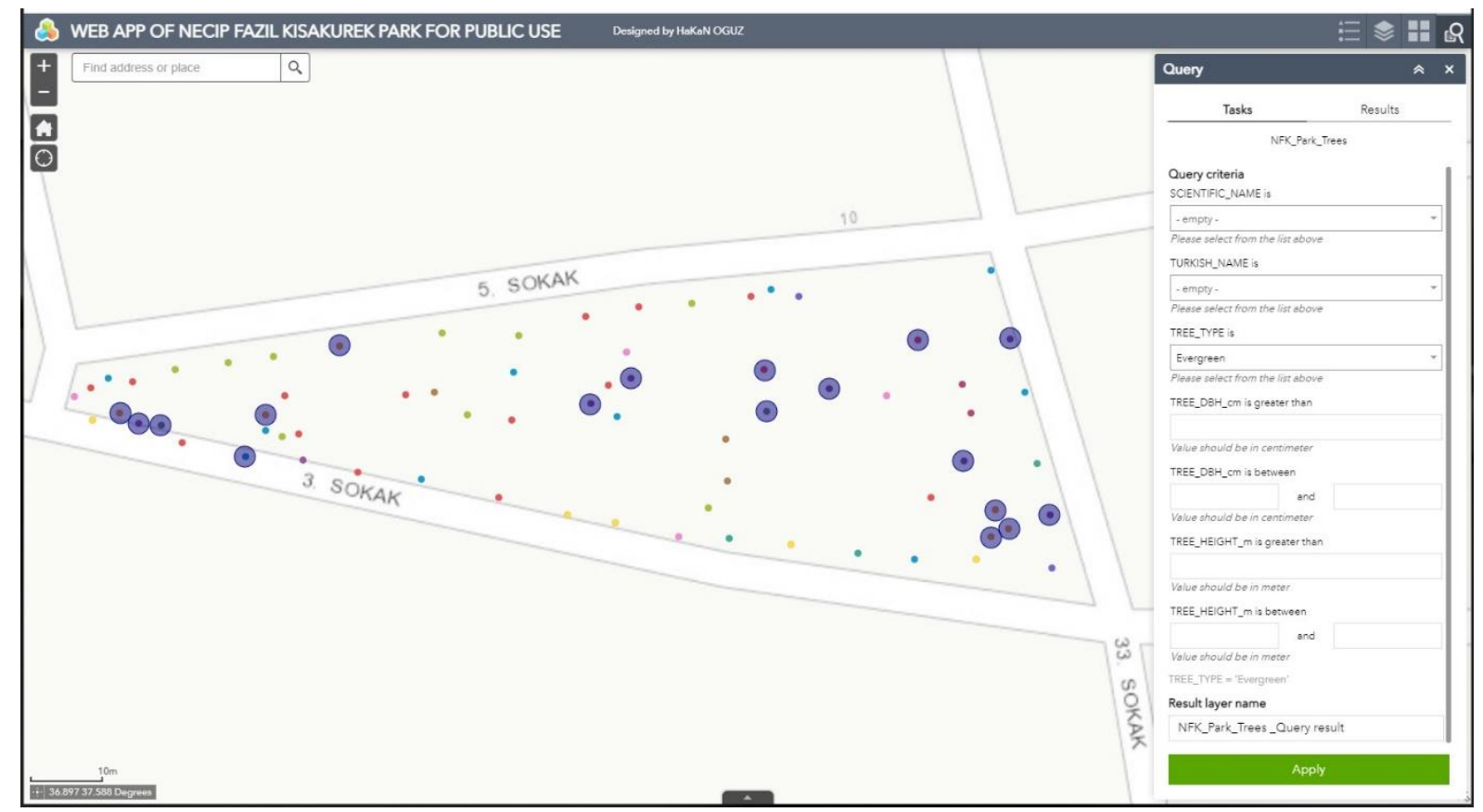

Figure 5. Query tool on web app

The second web application is designed for local government utilities only in order to manage tree information such as removing and/or inserting a tree or updating attributes of trees in the park. This app will only be accessible to local authorities and not to general public. The second web app designed for local authorities is illustrated in Figure 6 below. 


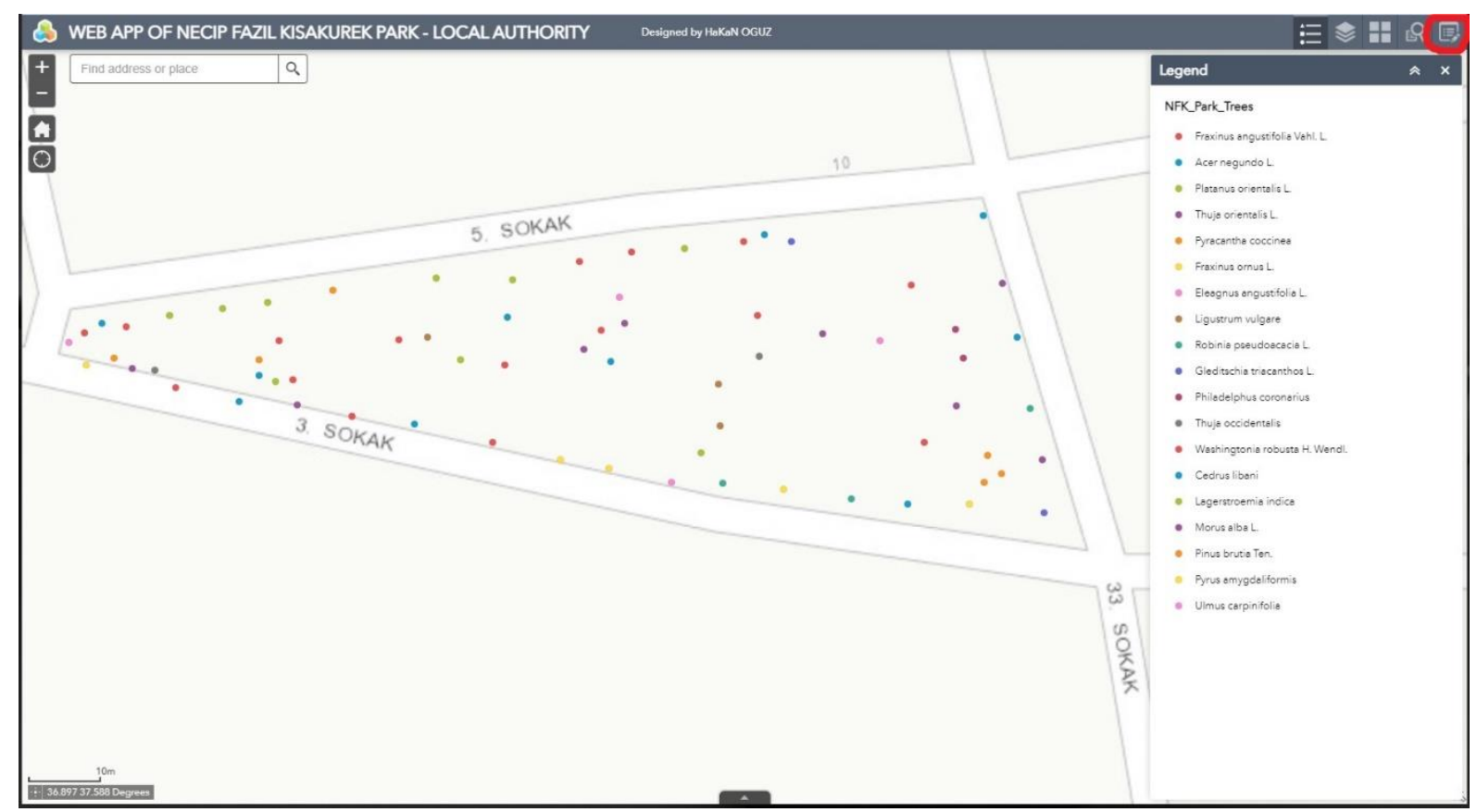

Figure 6. The web app for local authorities

The difference between app for general public and app for local authorities is the "edit" tool, which is located in the upper right corner of the second app as seen in Figure 6 above. The app for general public does not have the edit tool for obvious reasons. Tree attributes can be retrieved via pop-up window as shown in Figures 7-9 below.

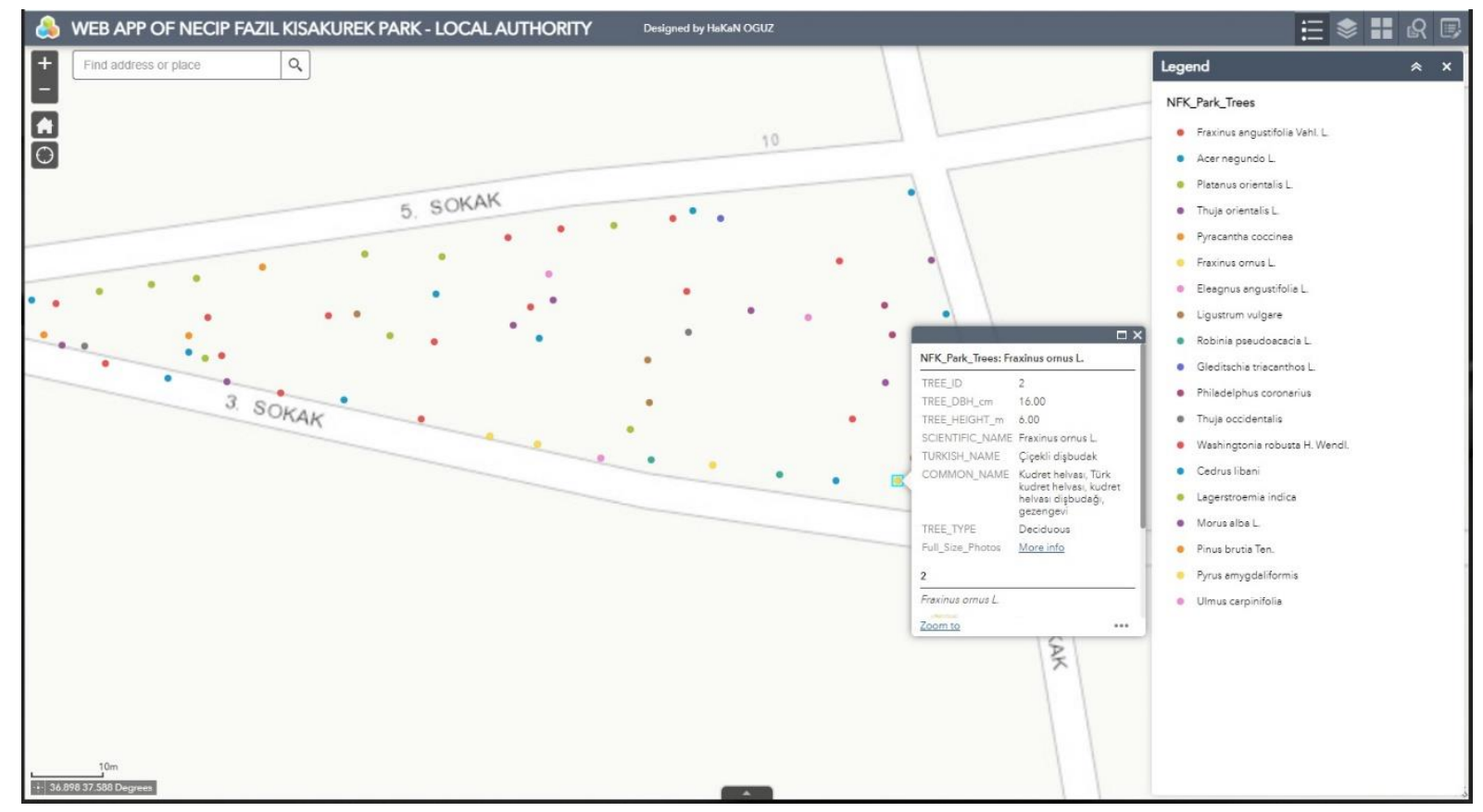

Figure 7. Pop-up window in the web app for local authorities 


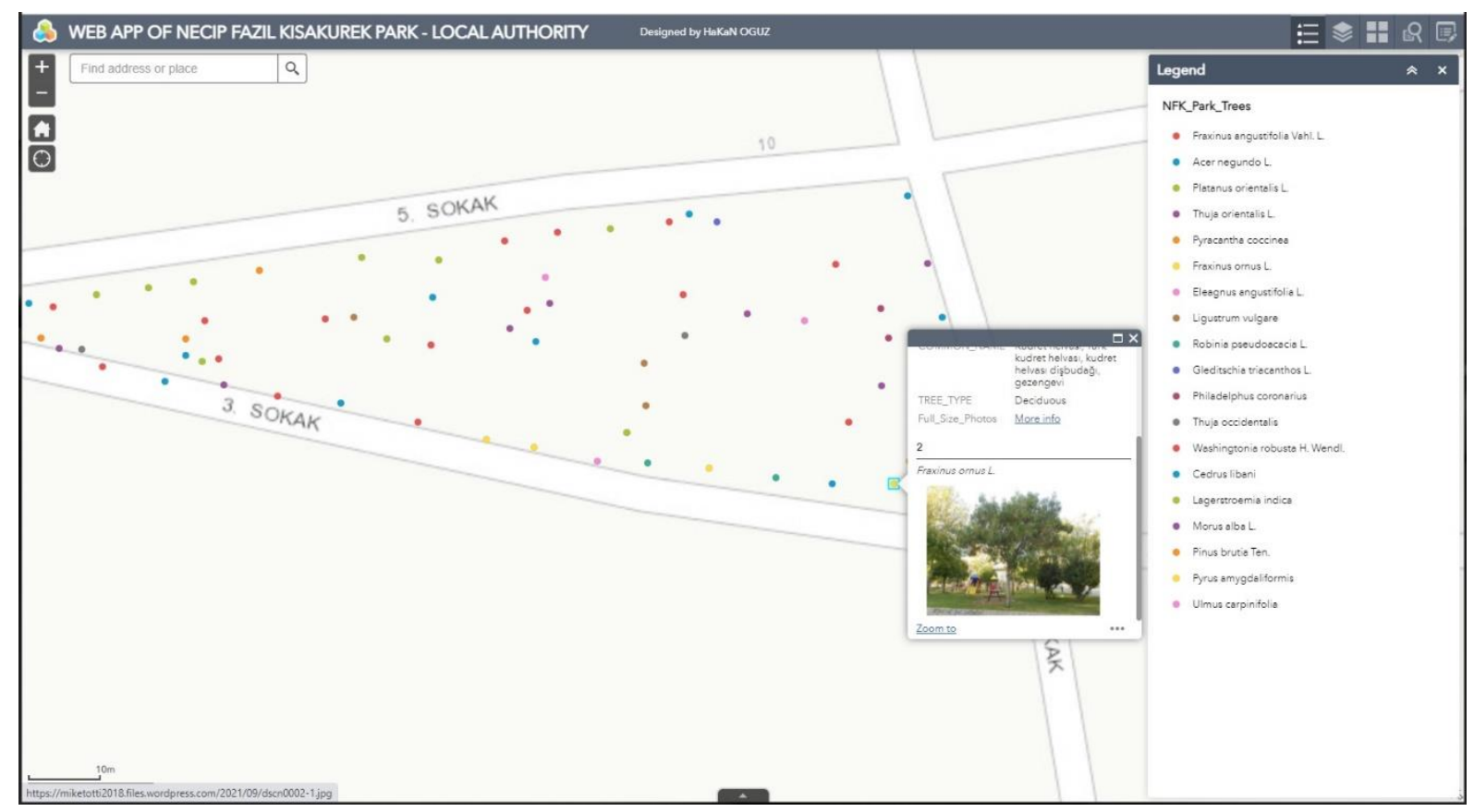

Figure 8. Pop-up window in the web app for local authorities

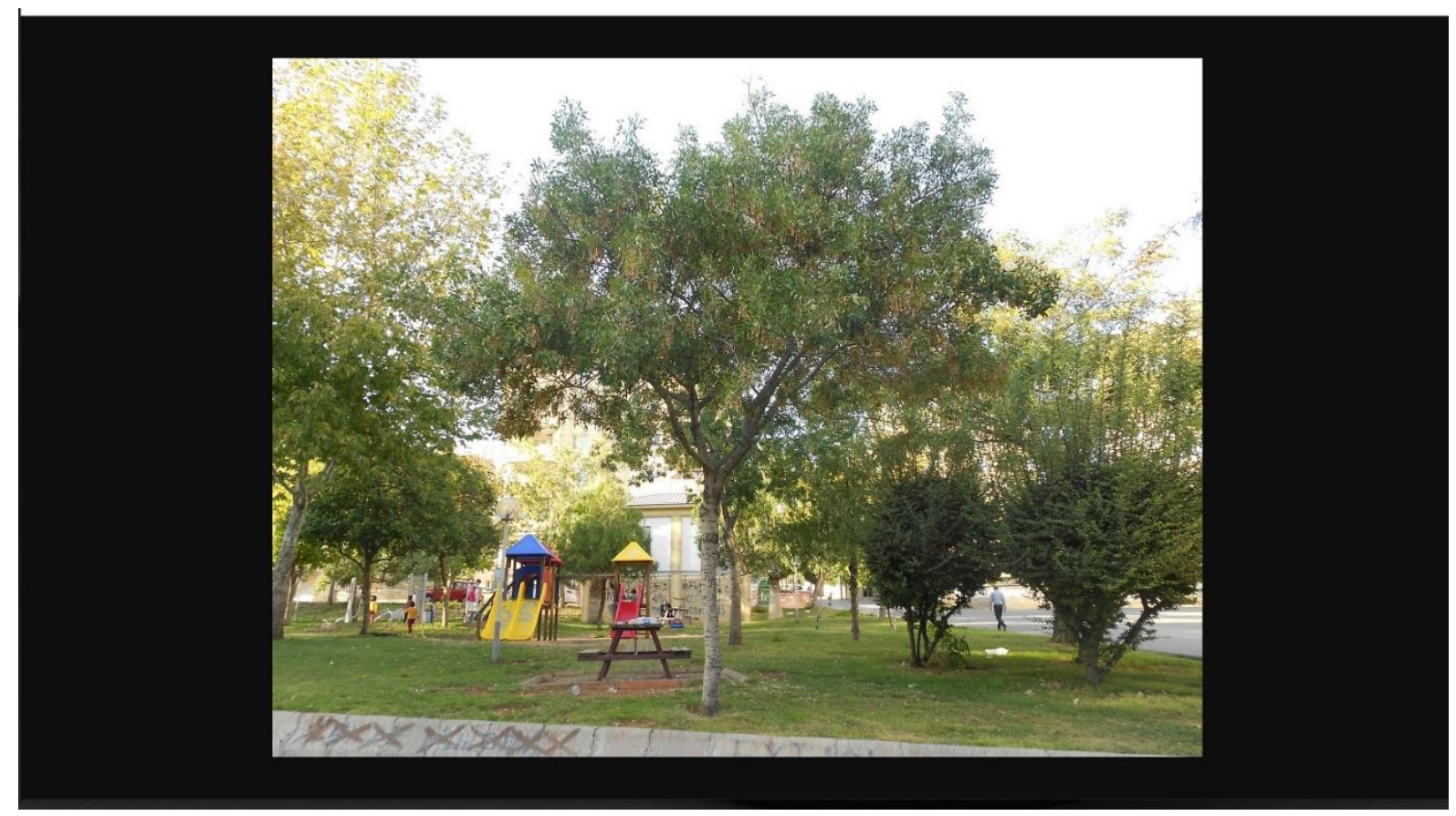

Figure 9. Full size photo in the web app for local authorities

This web app has query tool too as shown in Figure 10 below. Figure 11 illustrates the results of a query applied on Acer negundo. 


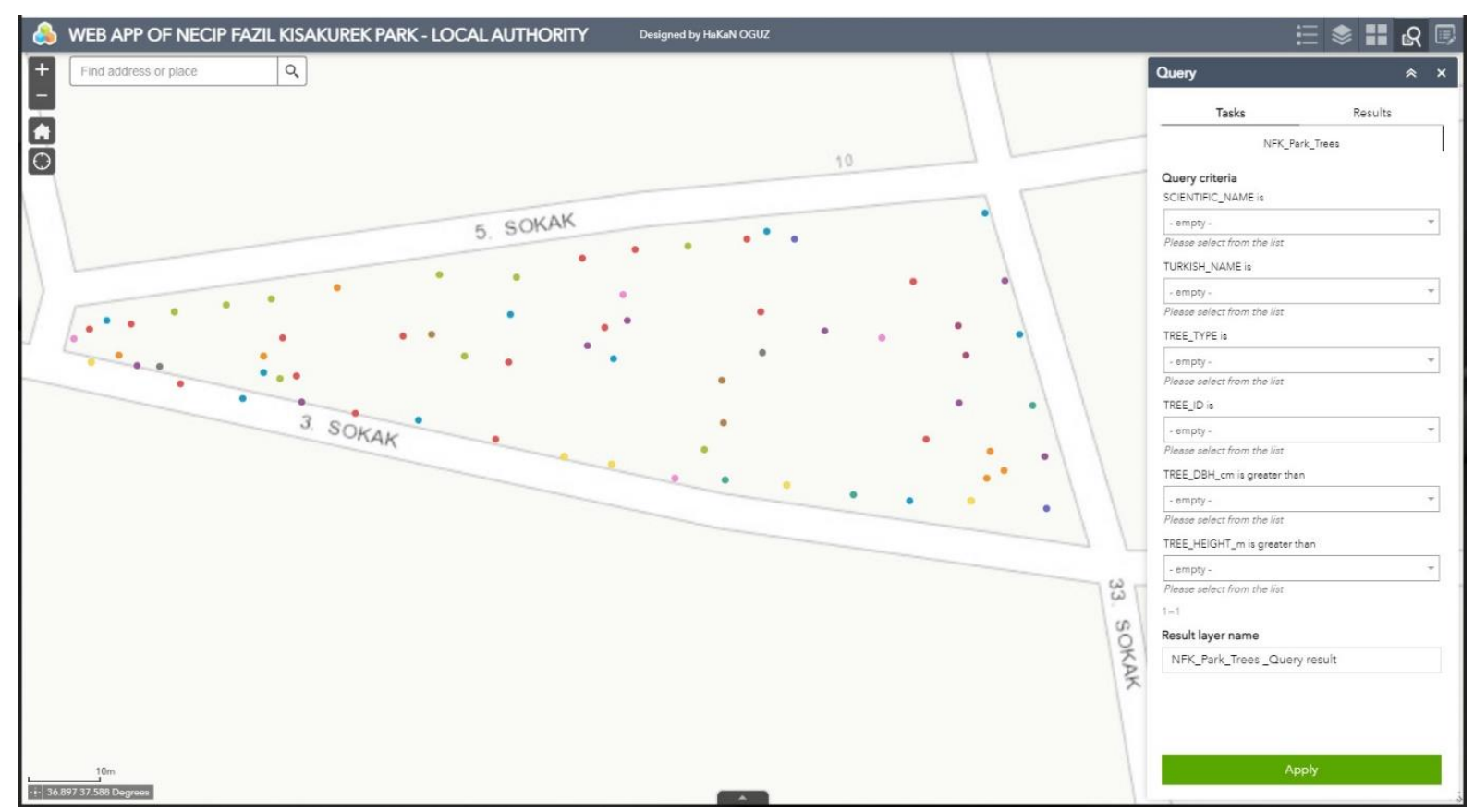

Figure 10. The query tool

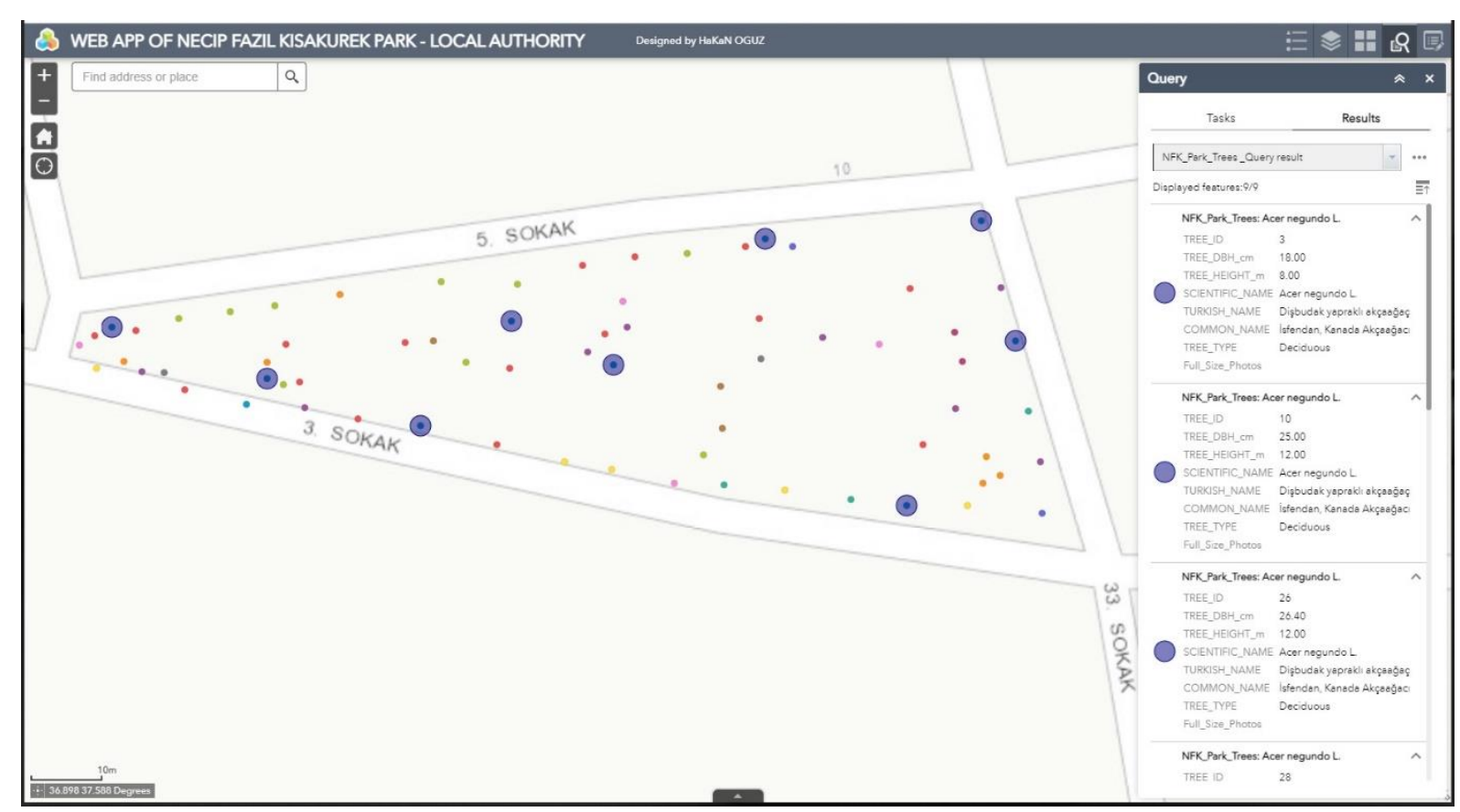

Figure 11. Query results

The most important tool of the app is the edit tool. The local authorities can update tree attributes using the edit tool as illustrated in Figure 12 below. 


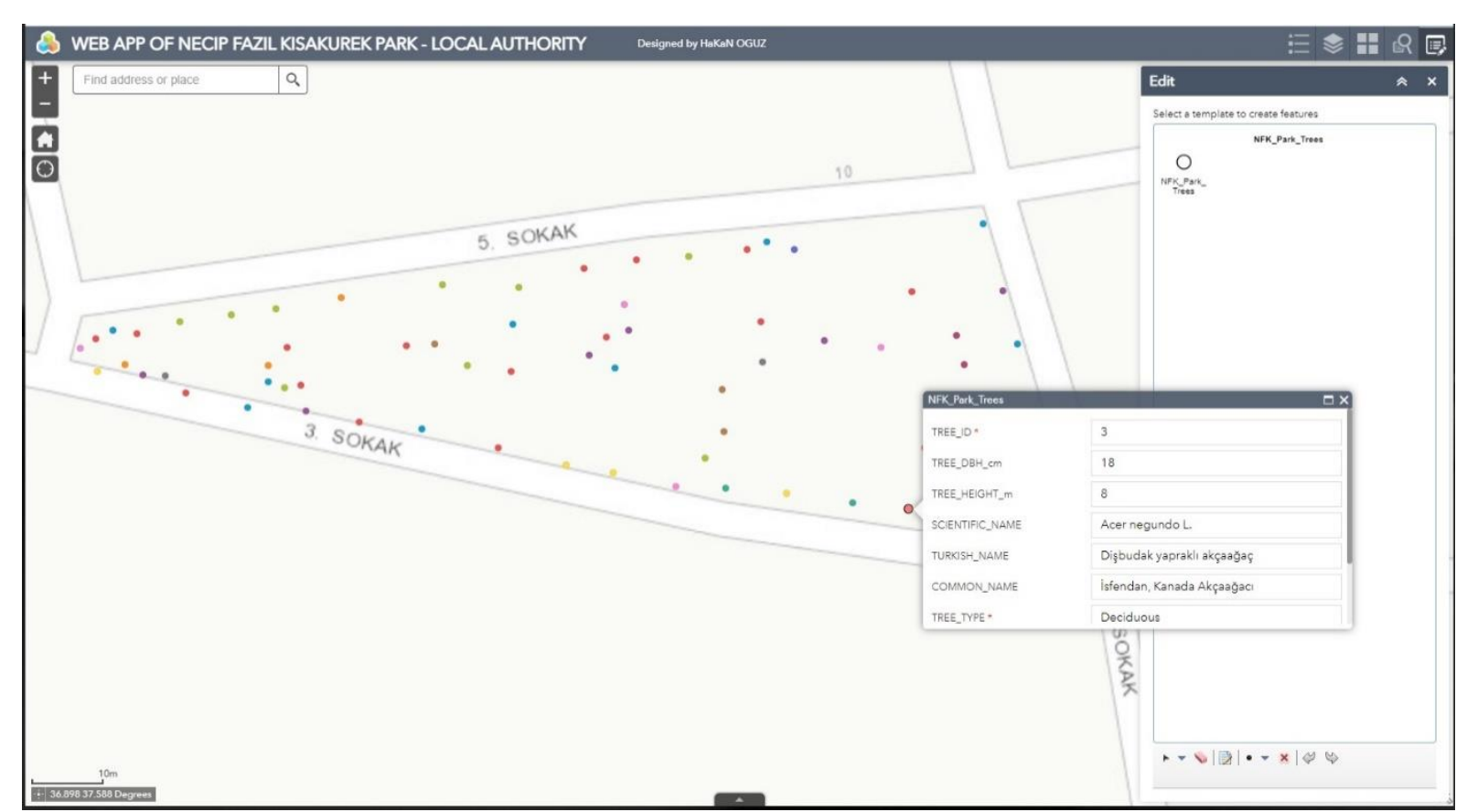

Figure 12. Tree attributes can be updated via the edit tool

Local managers may also insert trees to the database via edit tool as seen in Figure 13 below.

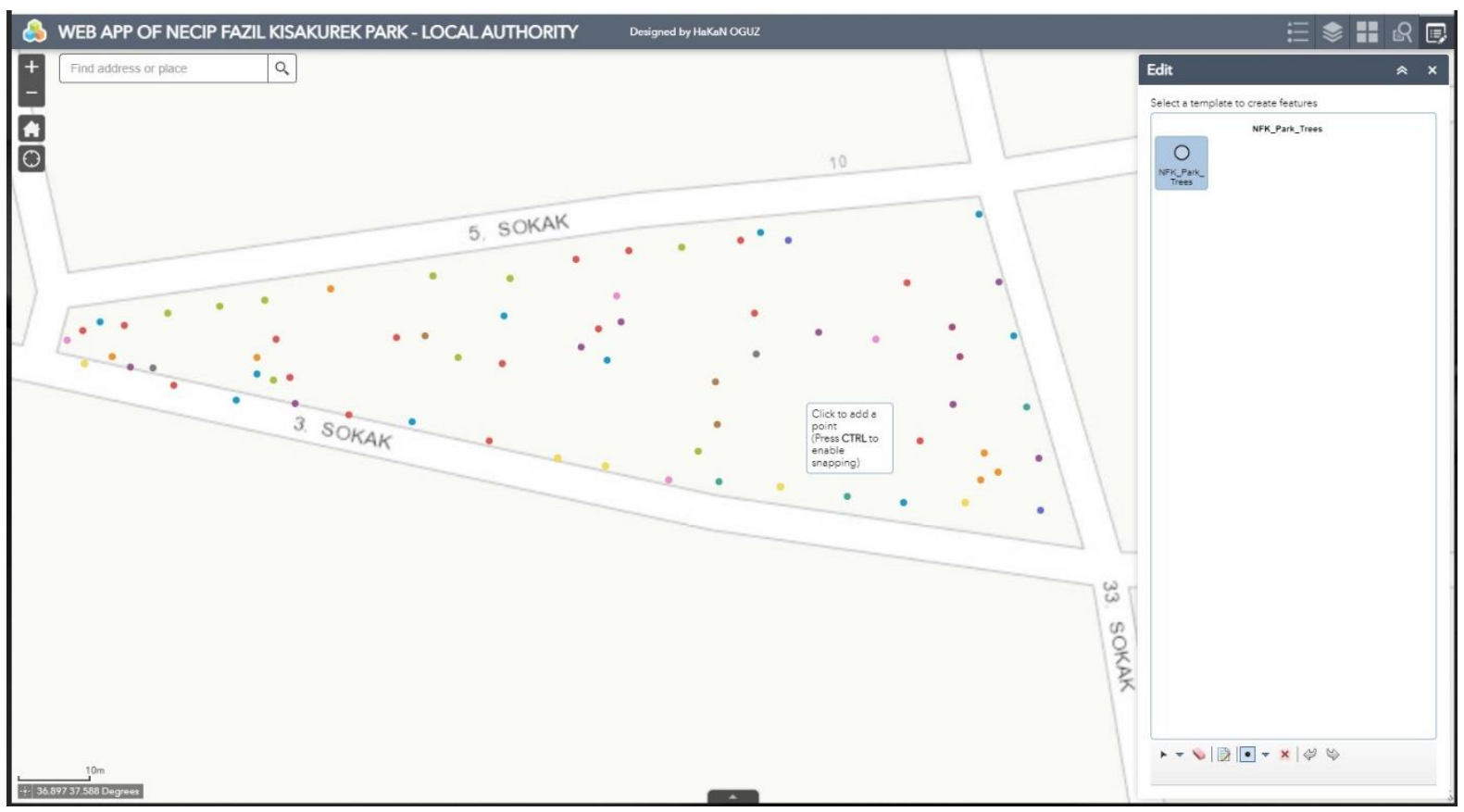

Figure 13. Edit tool can be used to insert tree in the web app

Web managers can change the base map in the app too. The attribute table is also accessible to the web managers to browse as illustrated in Figures 14 and 15 below. 


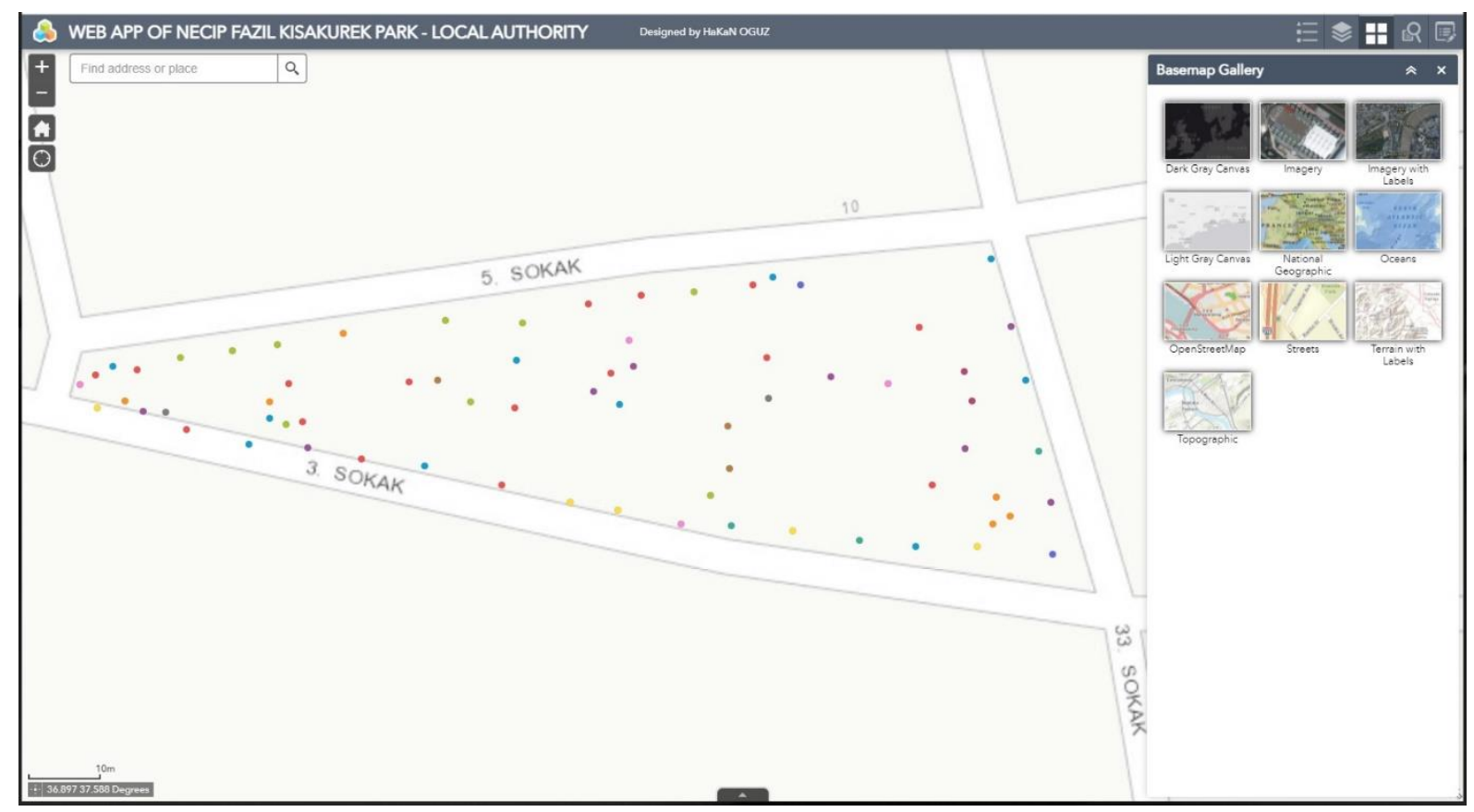

Figure 14. Basemap tool in the web app

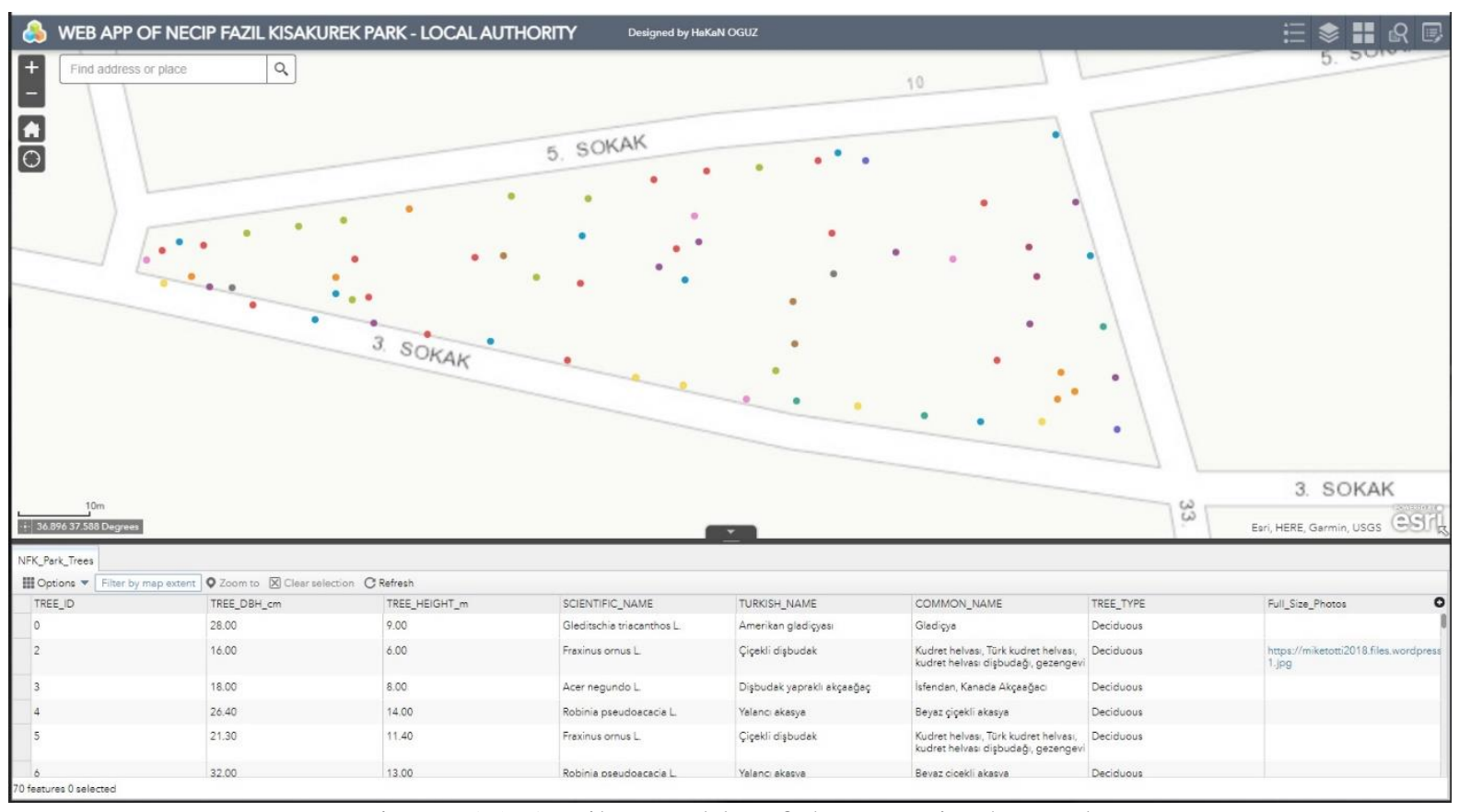

Figure 15. Attribute table of the trees in the park

\section{CONCLUSIONS}

The subject of this study was conducting an inventory on tree species and designing web apps with the developing technology. The technology is gaining importance today in terms of planning and design studies for the future. In our country, there are still deficiencies in reaching tree inventories on the web, so the implementation of this work in Turkey is quite important. 
The first web app developed in this study is publicly accessible to anyone who has access to the internet. Users can use this web app in personal computers, tablets, or smartphones. The second web app however was created for public authorities in order to manage the database. This web app is specifically designed to create maps, analyze data, share and collaborate. These apps were created with ArcGIS Online.

\section{AUTHOR CONTRIBUTIONS}

Milat Hasan Abdullah Abdullah: Conducting tree inventory. Hakan Oguz: Organizing and analyzing data, designing database and web application, writing, editing and reviewing the manuscript. Fatih Tonguc: Identification of tree species.

\section{REFERENCES}

Abd-Elrahman, A. H., Thornhill, M. E., Andreu, M. G. \& Es-cobedo, F. (2010) A community-based urban forest inventoryusing online mapping services and consumergrade digital images. Int J Appl Earth Obs Geoinf, 12(4), 249-26

Bruno, G., Gasca, E., \& Monaco, C. (2014) The efficient management of park resources: Naturaland cultural data in the Alpi Marittime Park area. Information Systems, 42, 78 88.

Gül, A., Özgüner, H., \& Serin, N. (2005) Kent Ormanlarının Yararları ve Kentsel Alanda İnsan-Orman Etkileşimi, 1. Çevre ve Ormancılık Şurası, Tebliğler, 2. Cilt, Mart, Antalya. 434-441.

Gül, A., Topay, M., Tuğluer, M., Uzun, Ö.F., \& Keleş, E. (2014) Kent Ağaçlarının CBS Ortamında Envanterı ve 3 Boyutlu Olarak Oluşturulması, III. Uluslararası Odun Dışı Orman Ürünleri Sempozyumu, Kahramanmaraş.

Li, M., \& Qi, M. (2003) MAPBOT: a Web based map information retrieval system. Information and Software Technology, 45(10), 691-698.

Oguz, H., Buyukturkmen, B., Kocahal, Y.E., \& Gitmis, E. (2018) Web-Based Tree Information System for Urban Parks: A Case Study of Alija Izetbegovic Park, Kahramanmaras-Turkey, In Proc: The International Congress of Science, Education and Technology Research, Odessa, Ukraine.

Oguz, H., \& Cayraz, O. (2019) Web-Based Urban Park Information System: A Case Study of Mothers Park, Gaziantep-Turkey, 1st International Applied Sciences Congress, 20-22 December, Malatya.

Oguz H., \& Isbir R. (2017) Developing a Web-Based Tree Information System: A Case Study of Cakmakci Sait Park - Kahramanmaras / Turkey. In Proc: The 3rd International Congress on Environmental Research and Technology (ICERAT), Belgrade, Serbia, p 21.

Oguz, H., Kıraççakal1, T. \& Kırteke, M. (2017) Web-Based GIS of the Haci Hasan Efendi Park, In Proc: International Advanced Researches and Engineering Congress, Osmaniye, Turkey.

Oguz, H. \& Kisakurek, S. (2016) Developing a Web-Based Tree Information System: A Case Study of Kilavuzlu Park - Kahramanmaras, 4th International Geography Symposium Kemer, Antalya, TURKEY p 165. 
Oguz, H. \& Kisakurek, S. (2016) UrbanParks - A Web-Based GIS Application: A Case Study of 12 Subat Park - Kahramanmaras, In Proc: 1st International Symposium of Forest Engineering and Technologies, (FETEC), Bursa, Turkey, p 65.

Oguz, H., Uzun, A. \& Kisakurek, S. (2020) Web-Based Tree Information System: A Case Study of Kahramanmaras, Turkey. Turkish Journal of Forest Science, 4(1), 160-171.

Sabuncu, A., Doğru, A., Özener, H., Turgut, B. \& Halıcıŏ̆lu, K. (2013) Anıt Ağaç Envanterinin Coğrafi Bilgi Sistemleri ile Oluşturulması, TMMMOB Coğrafi Bilgi Sistemleri Kongresi, 11-13 Kasım, Ankara.

Wolf, K. (1998) Urban Nature Benefits: Psycho-Social Dimensions of People and Plants, Center for Urban Horticulture, University of Washington. 